\title{
Differential Tolerances to Ametryne Among Six Genotypes of Giant Bermudagrass [Cynodon dactylon (L.) Pers. var. Aridus Harlan et de Wet], and Their Diallel Progenies ${ }^{1}$
}

\author{
G. Ramírez-Oliveras ${ }^{2}$
}

\begin{abstract}
Six parental giant bermudagrass [Cynodon dactylon (L.) Pers. var. Aridus Harlan et de Wet] clones and their $F$, progenies from 27 crosses out of a possible 30, were evaluated for their responses to two concentrations [ 5 and $10 \mathrm{p} / \mathrm{m}$ weight per volume (w/v)] of Ametryne [2-(ethylamino)4(esopropylamino)-6-(methylthio)-s-triazine].

There were significant differences among parents and progenies at 10 but not at $5 \mathrm{p} / \mathrm{m}$ Ametryne. Tolerant parents had more tolerant progenies than did susceptible parents, indicating that tolerance may be a heritable trait. Progenies had tolerance ratings consistently lower than midparent values, suggesting that susceptibility is partially dominant. General combining ability, but not specific combining ability, was significant for the $10 \mathrm{p} / \mathrm{m}$ test, suggesting that breeding programs for tolerance to Ametryne should proceed in terms of additive genes. Crosses of tolerant parents should be expected to produce a high proportion of tolerant progeny.
\end{abstract}

\section{INTRODUCTION}

Bermudagrass, Cynodon dactylon (L.) Pers., is a perennial highly competitive grass, important throughout the tropics and subtropics (6). It has spread around the world from its origin in tropical Africa and Indo-Malaysia (6). Probably the first deliberate introduction into the United States was in the eighteenth century (4).

There is evidence of genetic differentials in susceptibility to herbicides among bermudagrass clones $(1,8,10)$. Since weed control and field sanitation in bermudagrass-infested areas are often dependent upon herbicides, the investigation of such differentials assumes great importance. These differentials could be used in plant breeding programs.

In newly established sugarcane (Saccharum officinarum L.) fields, bermudagrass can become a serious weed if it is not controlled properly. The Hawaiian Sugar Planters' Association Reports for 1957 and 1960 $(2,3)$ mentioned bermudagrass strains highly tolerant to both Dalapon ${ }^{3}$

${ }^{1}$ Manuscript submitted to the Editorial Board January 19, 1976. Part of a thesis submitted in partial fulfillment of the requirements for the degree of Master of Science, University of Arizona.

${ }^{2}$ Research Assistant, Lajas Substation, Agricultural Experiment Station, Mayagüez Campus, University of Puerto Rico, Río Piedras, P.R.

3 Trade names are used in this publication solely for the purpose of providing specific information. Mention of a trade name does not constitute a guarantee or warranty of equipment or materials by the Agricultural Experiment Station of the University of Puerto Rico or an endorsement over other equipment or materials not mentioned. 
(2,2-dichloropropionic acid) and TCA (trichloroacetic acid). Another herbicide used in sugarcane fields is Ametryne [2-(ethylamino)-4-(isopropylamino)-6-(methylthio)-s-triazine]. Although no strains resistant to Ametryne have been reported, it is important to determine bermudagrass response to this herbicide because of its wide usage in sugarcane weed control.

Although there is a high correlation between resistance and extent of herbicide metabolism, even susceptible plants have some capability to detoxify triazine herbicides.

Differentials in response of sorghum [Sorghum bicolor (L). Muench.] to Atrazine [2-chloro-4-(ethylamino)-6-(isopropylamino)-s-triazine] and Simazine [2-chloro-4,6-bis-(ethylamino)-s-triazine] appear to be due to differential rates of degradation. Both herbicides are absorbed and translocated at the same rates, but Atrazine is detoxified (by conjugation to peptides) five times as rapidly as Simazine by the same mechanism $(9,12)$.

Anderson and Kneebone (1) reported that bermudagrass selections differed significantly in responses to Atrazine and Dalapon. Rochecouste (8) stated that biotypes of bermudagrass showed different inherent tolerances to TCA and Dalapon and that the tetraploids were more tolerant than the triploids. Half of the 30 bermudagrass selections studied by Shrader (10) were tolerant to either Dalapon or Paraquat (1,1'-dimethyl-4,4'-dipyridinium-bis-dimethyl sulfate). All four were tetraploids.

This study was done to determine whether there are genetically controlled differentials in response of giant bermudagrass clones to Ametryne and to evaluate the heritability of response differentials to Ametryne by screening both the parents and the diallel progenies.

\section{MATERIALS AND METHODS}

Research was conducted during 1974 in the greenhouses of the University of Arizona and the Agricultural Research Service, USDA, located on the University Campus and the Tucson Plant Material Center, Tucson, Arizona.

Six parental clones of giant bermudagrass were exposed in preliminary tests to three concentrations $[5,10$, and $15 \mathrm{p} / \mathrm{m}$ weight per volume $(\mathrm{w} / \mathrm{v})]$ of Ametryne. These tests were made in the University Campus greenhouse from February 5 through 26, 1974. The clones varied in their origins (table 1 ).

The six clones and $F_{1}$ seedlings were genetically the same as those used by Lira (19) in a previous study on water use efficiency. Parents and their $F_{1}$ progenies were evaluated in this study for reactions to Ametryne at 5 and $10 \mathrm{p} / \mathrm{m}(\mathrm{w} / \mathrm{v})$. The $15 \mathrm{p} / \mathrm{m}$ test was eliminated because it proved to be too lethal in preliminary tests. 
TABLE 1.-Origin and identification of parental clones of giant bermudagrass

\begin{tabular}{cll}
\hline Clone number & Arizona identification & \multicolumn{1}{c}{ Origin } \\
\hline 1 & Yakima & Yakima, Washington \\
2 & B 442 & Oklahoma State University \\
& & 8152 (Afghanistan) \\
3 & B 445 & P. I. 291 616 (South Africa) \\
4 & B $442 \mathrm{OP}_{1}$ & Open pollination progeny \\
5 & B $442 \mathrm{OP}_{2}$ & B 442, Arizona \\
& & Open pollination progeny \\
6 & B 273 & B 442, Arizona \\
& & Arizona selection from NK 37
\end{tabular}

Round tapered plastic containers $11.5 \mathrm{~cm}$ in diameter at the top, $8 \mathrm{~cm}$ at the bottom, and $6.5 \mathrm{~cm}$ deep were used to establish the cuttings. Three holes $3 \mathrm{~cm}$ in diameter were drilled through the base to allow entrance of nutrient and herbicide solution. Shallower containers 11.6 $\mathrm{cm}$ in diameter at the top, $9.2 \mathrm{~cm}$ at the bottom, and $4.4 \mathrm{~cm}$ deep were used to hold the nutrient and test solutions.

The narrower containers were filled with vermiculite to approximately $1.5 \mathrm{~cm}$ from the rim and placed within the shallower ones. The vermiculite was thoroughly wetted with tap water and the excess water was allowed to drain into the shorter support container. These two containers were used as one unit to culture the cuttings. The containers were placed on an outdoor bench sheltered by an aluminum louver shade $1.5 \mathrm{~m}$ above it. Four cuttings with three nodes each were placed in each container. There were four replicates of each genotype. As soon as new leaves appeared on the cuttings, they were transferred to the greenhouse. The containers were irrigated with $100 \mathrm{ml} /$ container of Hoagland's complete nutrient solution, regular strength (5), once every 7 days, and tap water every other day.

After 15 days in the greenhouse, parental clones and $F_{1}$ progeny plants were assigned randomly within complete blocks on the greenhouse bench. One container of each genotype was in each replicate. Ametryne, $80 \%$ WP was weighed to obtain the desired concentration of test solution when dissolved in $60 \mathrm{l}$ of tap water. The lower support containers were removed to let the containers drain before treatments were applied. After draining, both containers were set up as one unit again. Treatments consisted of one application of $125 \mathrm{ml}$ of test solution to each container. Routine watering with tap water or nutrient solution was continued after treatments.

The first test included two randomized complete blocks treated with $10 \mathrm{p} / \mathrm{m}$ Ametryne, and two as untreated checks. The second test was on the two check blocks. One was treated with $5 \mathrm{p} / \mathrm{m}$ Ametryne, the other kept as check, but treated and untreated containers were randomized together in a complete block design. At the end of the $5 \mathrm{p} / \mathrm{m}$ evaluation 
period both the treated and untreated containers were harvested for yields. After each evaluation period, treated containers were drained, rewatered with tap water, and kept in the greenhouse to determine recovery.

Evaluations of herbicide damage were made beginning 4 days after treatment and every other day thereafter for a total of 12,14, and 24 days during the 10 , first 5 , and second $5 \mathrm{p} / \mathrm{m}$ trials, respectively. Herbicide tolerance was evaluated qualitatively as follows: 9 , leaves green; 87 , leaves green with slight chlorosis; $6-5$, leaves yellow; 4-3, leaves yellow with white tips; and 2-1, leaves dead.

Three separate experiments were conducted. The first $(10 \mathrm{p} / \mathrm{m})$ was from July 22 through August 3, 1974, the second (5 p/m) was from September 5 through 19, 1974, and the third ( $5 \mathrm{p} / \mathrm{m})$ was from October 10 through November 4, 1974. A recording hygrothermograph was placed on the greenhouse bench (table 2).

\section{RESULTS AND DISCUSSION}

There were distinct differences among clones, with similar rankings in reaction to Ametryne treatments at all concentrations (table 3 ). The variance among clones was significantly greater than the clone $\times$ concentration variance. At $5 \mathrm{p} / \mathrm{m}$ there were slight herbicidal effects and little differentiation. Greatest differentiation among clones occurred at

TABLE 2.-Greenhouse temperature and relative humidity values

\begin{tabular}{|c|c|c|c|c|}
\hline \multirow{2}{*}{ Treatment } & \multicolumn{2}{|c|}{ Temperature } & \multicolumn{2}{|c|}{ Relative humidity } \\
\hline & Average & Range & Average & Range \\
\hline & \multicolumn{2}{|c|}{${ }^{\circ} \mathrm{C}$} & \multicolumn{2}{|c|}{$\%$} \\
\hline Preliminary & 26 & $24-27$ & 50 & $30-70$ \\
\hline $10 \mathrm{p} / \mathrm{m}(\mathrm{w} / \mathrm{v})$ & 36 & $32-39$ & 58 & $51-65$ \\
\hline \multicolumn{5}{|l|}{$5 \mathrm{p} / \mathrm{m}(\mathrm{w} / \mathrm{v})$} \\
\hline Test 1 & 34 & $31-37$ & 59 & $45-73$ \\
\hline Test 2 & 28 & $23-34$ & 66 & $46-87$ \\
\hline
\end{tabular}

TABLE 3. - Tolerance ratings ${ }^{1} 20$ days after treatment in preliminary tests of six giant bermudagrass clones with three concentrations of Ametryne

\begin{tabular}{ccccc}
\hline & \multicolumn{5}{c}{ Concentrations in $\mathrm{p} / \mathrm{m}(\mathrm{w} / \mathrm{v})-$} \\
\cline { 2 - 5 } Clone No. & \multicolumn{1}{c}{10} & 15 & Mean \\
\hline 4 & 5 & $6.3 \mathrm{a}$ & $5.1 \mathrm{a}$ & $6.7 \mathrm{a}$ \\
1 & $8.7 \mathrm{a}^{2}$ & $5.7 \mathrm{ab}$ & $4.0 \mathrm{ab}$ & $5.9 \mathrm{ab}$ \\
2 & $8.0 \mathrm{ab}$ & $5.6 \mathrm{ab}$ & $3.4 \mathrm{ab}$ & $5.6 \mathrm{ab}$ \\
3 & $7.9 \mathrm{ab}$ & $4.9 \mathrm{ab}$ & $4.1 \mathrm{ab}$ & $5.3 \mathrm{~b}$ \\
6 & $6.9 \mathrm{~b}$ & $3.9 \mathrm{bc}$ & $3.4 \mathrm{ab}$ & $5.0 \mathrm{bc}$ \\
5 & $7.6 \mathrm{ab}$ & $2.9 \mathrm{c}$ & $2.4 \mathrm{~b}$ & $4.1 \mathrm{c}$ \\
\hline
\end{tabular}

${ }^{1}$ Ratings of 1 to 9 were used, where 9 was best.

${ }^{2}$ Mean values in the same column bearing unlike letters differ significantly $(\mathrm{P}=.05)$. 
$10 \mathrm{p} / \mathrm{m}$. At $15 \mathrm{p} / \mathrm{m}$, damage was more severe and the range was again reduced. Clone 4 had the highest average tolerance rating at each concentration. Clone 5 had the lowest tolerance rating at each concentration. Clones 4 and 5 are sisters, open-pollination progeny of clone 2 (table 1) and suggest that a broad tolerance range is operating under genetic control. Duncan's multiple range test shows that clone 4 differed significantly from clones 3,5 , and 6 for the mean tolerance values at some concentrations. At $10 \mathrm{p} / \mathrm{m}$, clone 4 was significantly different from clones 6 and 5 , while at $15 \mathrm{p} / \mathrm{m}$ clone 4 was significantly different from clone 5 .

On the basis of differentiations found in the preliminary tests of the parental clones, the $10 \mathrm{p} / \mathrm{m}$ concentration was chosen for final testing. The second rating date ( 8 days after treatment) was chosen to evaluate plant response to herbicide effects because greatest differentiation among parents and progenies within crosses occurred on this date. Twelve days after treatment in the final $10 \mathrm{p} / \mathrm{m}$ test, $90 \%$ of the plants rated 1. Average tolerance ratings for check and treated plants (parents and progenies), 8 days after treatment, were 8 and 4 , respectively. Parental clones differed significantly with the same ranking as in preliminary tests (table 4).

Clone 4 was significantly more tolerant (table 4 ) than all parental clones other than clone 2 . There was a high correlation $(r=.72)$ between preliminary $10 \mathrm{p} / \mathrm{m}$ parental tolerance ratings and those from final 10 $\mathrm{p} / \mathrm{m}$ testing. Since temperatures averaged $26^{\circ} \mathrm{C}$ during preliminary testing and $36^{\circ} \mathrm{C}$ during the final test, the lower ratings can probably be attributed to temperature intensification of herbicide effects $(11,13)$.

Differences among parents were significant $(\mathrm{P}=.05)$ when analyzed separately. Analysis of progeny averages showed no significance. $\mathrm{Pa}-$ rental and progeny rankings were similar (table 4), but lower for progenies than for their parents.

TABLE 4.-Tolerance ratings ${ }^{1}$ at $10 \mathrm{p} / \mathrm{m}$, w/v Ametryne for six giant bermudagrass clones and their $\mathrm{F}$, progenies

\begin{tabular}{|c|c|c|c|c|c|c|c|c|}
\hline \multirow{2}{*}{$\begin{array}{l}\text { Female } \\
\text { parents }\end{array}$} & \multicolumn{6}{|c|}{ Male parents } & \multirow{2}{*}{$\begin{array}{l}\text { Cross } \\
\text { means }\end{array}$} & \multirow{2}{*}{$\begin{array}{c}\text { Parental } \\
\text { means }\end{array}$} \\
\hline & 1 & 2 & 3 & 4 & 5 & 6 & & \\
\hline 1 & - & 3.8 & 5.1 & 4.8 & 一 & 4.0 & 4.4 & $4.5 \mathrm{~b}^{2}$ \\
\hline 2 & 4.2 & - & 4.2 & 4.4 & 4.3 & 4.5 & 4.3 & $5.0 \mathrm{ab}$ \\
\hline 3 & 4.3 & 4.5 & - & 4.3 & 4.2 & 一 & 4.3 & $4.0 \mathrm{~b}$ \\
\hline 4 & - & 5.3 & 4.5 & - & 3.7 & 4.4 & 4.5 & $6.0 \mathrm{a}$ \\
\hline 5 & 5.0 & 3.0 & 4.3 & 4.2 & - & 3.2 & 3.9 & $4.0 \mathrm{~b}$ \\
\hline 6 & 4.1 & 4.9 & 4.0 & 4.7 & 3.5 & - & 4.2 & $4.5 \mathrm{~b}$ \\
\hline $\begin{array}{l}\text { Cross } \\
\text { means }\end{array}$ & 4.4 & 4.3 & 4.4 & 4.5 & 3.9 & 4.0 & 4.3 & 4.7 \\
\hline
\end{tabular}

${ }^{1}$ Ratings of 1 to 9 were used where 9 was best.

${ }^{2}$ Mean values in the same column bearing unlike letters differ significantly $(\mathrm{P}=.05)$. 
Although herbicide effects were less apparent in tolerant plants and slower to become visible, vigor was reduced. All but three plants died, even though the herbicide was flushed from the system. Two of the three survivors were progeny of tolerant clone 4.

Severe damage (dead leaves and stems) at $10 \mathrm{p} / \mathrm{m}$ suggested that further testing be done at $5 \mathrm{p} / \mathrm{m}$. However, lower greenhouse temperatures, especially during the second $5 \mathrm{p} / \mathrm{m}$ test (table 5), increased the apparent plant tolerance to the herbicide.

Overall tolerance ratings for the first $5 \mathrm{p} / \mathrm{m}$ test were lower than those for the second $5 \mathrm{p} / \mathrm{m}$ test. Temperatures during the first $5 \mathrm{p} / \mathrm{m}$ test averaged $34^{\circ} \mathrm{C}$, while those during the second $5 \mathrm{p} / \mathrm{m}$ averaged $28^{\circ} \mathrm{C}$, only $2^{\circ} \mathrm{C}$ above the preliminary test. The greatest differentiation among parents and progenies for tolerance was obtained 14 days after treatment for the first $5 \mathrm{p} / \mathrm{m}$ test, and 25 days after treatment for the second 5 $\mathrm{p} / \mathrm{m}$ test, illustrating again the effect of higher temperatures.

In contrast to the significant $(r=.72)$ correlation between $10 \mathrm{p} / \mathrm{m}$ tolerance ratings for parents (preliminary and final), the correlation for the $5 \mathrm{p} / \mathrm{m}$ tests was not significant $(r=.32)$. Parental tolerance ratings for 5 and $10 \mathrm{p} / \mathrm{m}$ tests were positively correlated $(r=.59)$. Tolerance ratings for parental clones were higher at the preliminary test than at the final $5 \mathrm{p} / \mathrm{m}$ test (tables 3 and 5 ). Parental means were higher than cross means except for clones 1 and 6 .

In contrast to the $10 \mathrm{p} / \mathrm{m}$ test, most plants survived treatment with 5 $\mathrm{p} / \mathrm{m}$. Tolerance ratings were positively correlated with yields of treated clones $(r=.52)$. Ratios of yields of treated to check containers were also positively correlated $(r=.44)$ with $5 \mathrm{p} / \mathrm{m}$ tolerance ratings. However, these suggest that yields of treated clones were related as much to original yields as to herbicide effects. Yields of check containers were positively correlated $(r=.49)$ with $5 \mathrm{p} / \mathrm{m}$ tolerance ratings for parents and progenies and with transpiration values $(19)(r=.43)$. Yields of

TABLE 5. - Tolerance ratings' at $5 \mathrm{p} / \mathrm{m}$, w/v Ametryne for six giant bermudagrass clones and their $\mathrm{F}_{1}$ progenies

\begin{tabular}{ccccccccc}
\hline $\begin{array}{c}\text { Female } \\
\text { parents }\end{array}$ & \multicolumn{9}{c}{ Male parents } & \multicolumn{2}{c}{$\begin{array}{c}\text { Cross } \\
\text { means }\end{array}$} & $\begin{array}{c}\text { Parental } \\
\text { means }\end{array}$ \\
\cline { 2 - 6 } & 1 & 2 & 3 & 4 & 5 & 6 & & \\
\hline 1 & - & 5.8 & 5.3 & 6.3 & - & 6.2 & 5.9 & $5.5 \mathrm{a}^{2}$ \\
2 & 5.6 & - & 5.0 & 4.5 & 5.1 & 5.6 & 5.2 & $6.5 \mathrm{a}$ \\
3 & 5.3 & 5.7 & - & 5.8 & 6.8 & - & 5.9 & $6.0 \mathrm{a}$ \\
4 & - & 3.8 & 6.0 & - & 6.3 & 5.6 & 5.4 & $6.5 \mathrm{a}$ \\
5 & 5.0 & 3.5 & 6.0 & 5.5 & - & 4.3 & 4.9 & $6.0 \mathrm{a}$ \\
6 & 6.6 & 5.1 & 5.9 & 5.7 & 5.8 & - & 5.8 & $5.5 \mathrm{a}$ \\
Cross & 5.6 & 4.8 & 5.6 & 5.6 & 6.0 & 5.4 & 5.5 & 6.0 \\
means & & & & & & & & \\
\hline
\end{tabular}

${ }^{1}$ Ratings of 1 to 9 were used where 9 was best.

${ }^{2}$ Mean values in the same column bearing unlike letters differ significantly $(\mathrm{P}=.05)$. 
TABLE 6.-Tolerance ratings at 5 and $10 \mathrm{p} / \mathrm{m}$, w/v Ametryne for midparents and corresponding $\mathrm{F}_{1}$ crosses of giant bermudagrass

\begin{tabular}{ccccc}
\hline \multirow{2}{*}{ Combined reciprocals } & \multicolumn{2}{c}{$5 \mathrm{p} / \mathrm{m}, \mathrm{w} / \mathrm{v}$} & \multicolumn{2}{c}{$10 \mathrm{p} / \mathrm{m}, \mathrm{w} / \mathrm{v}$} \\
\cline { 2 - 5 } & Midparent & Cross & Midparent & Cross \\
\hline $1 \times 2,2 \times 1$ & 6.0 & 5.7 & 4.8 & 4.0 \\
$1 \times 3,3 \times 1$ & 5.8 & 5.3 & 4.3 & 4.7 \\
$1 \times 4,-\overline{8}$ & 6.0 & 6.3 & 5.3 & 4.8 \\
\hline $1 \times 6,6 \times 1$ & 5.8 & 5.0 & 4.3 & 5.0 \\
$2 \times 3,3 \times 2$ & 5.5 & 6.4 & 4.5 & 4.1 \\
$2 \times 4,4 \times 2$ & 6.3 & 5.4 & 4.5 & 4.4 \\
$2 \times 5,5 \times 2$ & 6.5 & 4.2 & 5.5 & 4.9 \\
$2 \times 6,6 \times 2$ & 6.3 & 4.3 & 4.5 & 3.7 \\
$3 \times 4,4 \times 3$ & 6.0 & 5.4 & 4.8 & 4.7 \\
$3 \times 5,5 \times 3$ & 6.3 & 5.9 & 5.0 & 4.4 \\
& 6.0 & 6.4 & 4.0 & 4.3 \\
$4 \times 5,5 \times 3$ & 5.8 & 5.9 & 4.3 & 4.0 \\
$4 \times 6,6 \times 4$ & 6.3 & 5.9 & 5.0 & 4.0 \\
$5 \times 6,6 \times 5$ & 6.0 & 5.7 & 5.1 & 4.6 \\
\hline
\end{tabular}

both treated and untreated clones were significantly correlated for progenies (.75) and parents (.60). Tolerance ratings at $5 \mathrm{p} / \mathrm{m}$ probably reflect intrinsic vigor as much as actual herbicide tolerance.

The critical differentiation among parents and among progenies was obtained with $10 \mathrm{p} / \mathrm{m}$ Ametryne. Parental clones 4 and 2 were most tolerant having average ratings of 6 and 5 , respectively. Parental clones 5 and 6 were least tolerant with average ratings of 3 and 4 , respectively. Clones 4 and 2 produced more tolerant progenies (4.4 average tolerance rating) than did clones 5 and 6 , the latter having tolerance ratings averaging 4.0.

A comparison of midparent values with combined reciprocal progeny values (table 6) shows that progenies tended to have lower tolerance ratings than expected on the basis of parent values. Parental clones 1 and 3 are involved in all of these crosses and also bear intermediate tolerance ratings (tables 2 and 3 ).

General combining ability (gca) was significant for the $10 \mathrm{p} / \mathrm{m}$ test. Proceeding on the basis of gca from midparent values allowed separation of the most promising crosses. Breeding for tolerance should proceed in terms of generally additive genes. Since susceptibility is apparently dominant over tolerance, resistant plants when combined would probably tend to breed true for tolerance.

\section{RESUMEN}

Seis clones de yerba bermuda y sus progenies $F_{1}$ se evaluaron para resistencia a dos concentraciones (5 y 10 p.p.m.) de Ametryne. Los padres resistentes al yerbicida produjeron un mayor número de plantas resistentes que los padres susceptibles, indicando que el grado de resistencia en la yerba bermuda está genéticamente controlado. Cuando se comparan los valores, los promedios de los padres con los de sus progenies, éstos, son más 
bajos que aquéllos, señalando que la susceptibilidad al yerbicida es parcialmente dominante a la resistencia.

Estos resultados, además de proveer un mejor conocimiento de la yerba bermuda y su reacción al Ametryne sugieren que se conseguiría un control más eficaz de esta yerba si se alternaran o se usaran combinaciones de yerbicidas, evitándose así la propagación y establecimiento de cepas resistentes. Diferentes grados de resistencia, genéticamente controlados, se pueden incorporar a variedades propagadas por semillas para usarse en programas de control de malas yerbas planificados de antemano.

\section{LITERATURE CITED}

1. Anderson, L. G., and Kneebone, W. R., Differential responses of Cynodon dactylon (L.) Pers. selections to three herbicides, Crop Sci. 9: 599-601, 1969.

2. Anonymous, Herbicide-tolerant strains of weeds, Hawaii Sugar Plant Assoc. Exp. Sta. Comm. Rep., p. 69-72, 1957.

3. Anonymous, Strains of bermudagrass vary in herbicide tolerance, Hawaii Sugar Plant Assoc. Exp. Sta. Comm. Rep., p. 74, 1960.

4. Hanson, A. A., and Carnahan, H. L., Breeding perennial forage grasses, USDA Tech. Bull. No. 1145, 116 pp., 1956.

5. Hoagland, D. R., and Arnon, D. I., The water culture method for growing plants without soil, Calif. Agr. Exp. Sta. Circ. 347, 39 pp., 1950.

6. Kneebone, W. R., Bermudagrass-worldly, wily, wonderful weed. Econ. Bot. 20: 947, 1966.

7. Lira, M. de A., Diallel analysis of water-use efficiency in giant bermudagrass Cynodon dactylon (L.) Pers, var. aridus Harlan et de Wet. Ph.D. Diss. Univ. Ariz. Libr., Tucson, Ariz., 54 pp., 1974.

8. Rochecouste, E., Studies on the biotypes of Cynodon dactylon (L.) Pers., Weed Sci. 2: $136-45,1962$.

9. Roeth, F. W., and Lavy, T. L., Atrazine translocation and metabolism in sudangrass, sorghum, and corn, Weed Sci 19: 98-101, 1971.

10. Shrader, T. H., Field responses of selected bermudagrass clones to foliar applications of Dalapon and Paraquat, M.S. Thesis, Univ. Ariz. Libr., Tucson, Ariz., 69 pp., 1972.

11. Smith, C. N., Jr., and Nalewaja, J. D., Uptake and translocation of foliarly applied Atrazine, Weed Sci. 20: 36-40, 1972.

12. Thompson, L., Jr., Metabolism of Simazine and Atrazine by wild cane, Weed Sci. 20: $153-5,1972$.

13. Vostral, H. L., and Hamilton, R. H., The leaf concentration of Atrazine in cereal crops as related to tolerance, Weed Sci. 16: 7-10, 1968. 